JANUSZ RUSZKOWSKI

DOI : $10.14746 /$ rie.2015.9.2

Jean Monnet Chair ad Personam

Uniwersytet Szczeciński

\title{
Demokracja ponadnarodowa w Unii Europejskiej. Wstępna analiza teoretyczna
}

\section{Ponadnarodowość jako paradygmat teoretyczny w badaniach}

Demokracja już dawno przekroczyła granice państw i ujawnia się w różnych strukturach międzynarodowych tak o charakterze transnarodowym (np. europartie), czy międzyrządowym (np. Rada Europy), jak i o charakterze ponadnarodowym (optymalnym przykładem rozwiązań ponadnarodowych w stosunkach międzynarodowych jest Unia Europejska, w której są one najbardziej zaawansowane) ${ }^{1}$. Oczywiście nie można zapominać, że w UE, która jest strukturą niezwykle złożoną i skomplikowaną, równolegle z rozwiązaniami ponadnarodowymi funkcjonują rozwiązania międzyrządowe (np. system Rady Europejskiej, Rady Unii Europejskiej) oraz transnarodowe (np. grupy polityczne w Parlamencie Europejskim). Analiza w opracowaniu koncentruje się jednak tylko na poziomie ponadnarodowym UE. To zastrzeżenie implikuje kolejne, według którego jeżeli poszukujemy demokracji tylko ponadnarodowej w UE, to oczywiście przy zastosowaniu koncepcji wielopoziomowego zarządzania (Multi-level Governance - MLG) odrzucimy na potrzeby tego opracowania analizę demokracji na poziomie narodowym oraz demokracji na poziomie regionalnym.

W systemie politycznym Unii Europejskiej opartym na MLG można mówić o demokracji wielopoziomowej (multi-level democracy), która jako tzw. crisp levels democracy występuje nie tylko na każdym poziomie konwencjonalnym MLG (regionalnym, narodowym, ponadnarodowym), ale także jako tzw. fuzzy levels democracy objawia się pomiędzy tymi poziomami lub na ich styku, czyli na tzw. poziomach rozmytych (np.

1 Por. na temat demokracji poza państwem narodowym: Ph. Schmitter, T. Lynn Karl, What Democracy is - And Is Not, „Journal of Democracy”, vol. 2, Summer 1991, s. 76; K. A. Wojtaszczyk, J. Szymańska, Deficyt demokracji w Unii Europejskiej, Warszawa 2012; Democracy beyond the State. The European Dilemma and the Emerging Global Order, eds. M. T. Greven, L. W. Pauly, Lanham, Rowman-Littlefield 2000; M. Zürn, Democratic Governance beyond the Nation-State. The European Union and Other International Institutions, „European Journal of International Relations”, vol. 6, June 2000; R. Menasse, Demokracja nie musi być narodowa. Unia Europejska: pokój na kontynencie a oburzenie obywateli, Warszawa 2013; B. Eberlein, E. Grande, Beyond delegation: transnational regulatory regimes and the EU regulatory state, „Journal of European Public Policy” 2005, vol. 12, $\mathrm{nr}$ 1; W. Schmidt, Democracy in Europe. The EU and National Polities, Oxford 2006; D. Held, Democracy and the Global Order. From the Modern State to Cosmopolitan Governance, Cambridge 1995; M. Avbelj, J. Komarek, Constitutional Pluralism in the European Union and Beyond, Bloomsbury Publishing 2012. 
poziom regionalno-narodowy lub narodowo-ponadnarodowy itd.), których nie da się przypisać wprost tylko do jednego ze znanych poziomów konwencjonalnych ${ }^{2}$.

Skoro analiza w opracowaniu obejmuje demokrację ponadnarodową, to w ujęciu szerszym będzie to sekwencyjna (dotycząca tylko jednego poziomu) analiza crisp levels democracy ulokowanej na jednym poziomie konwencjonalnym (ponadnarodowym) w MLG. Poziom ponadnarodowy w UE niemal idealnie pokazuje procesy o charakterze pozapaństwowym (niepaństwowym). Demokracja ujawniająca się właśnie na tym poziomie oznacza, że nie jest ona przypisana do państwa $\mathrm{i}$ - co istotne - w praktyce dowodzi, że wcale nie musi ona mieć charakteru narodowego.

Poszukiwanie demokracji w Unii Europejskiej nie jest zabiegiem alternatywnym, ani tym bardziej przeciwbiegunowym wobec badania deficytu demokracji ${ }^{3}$, który jest już terminem niemal klasycznym w studiach europejskich, bowiem „deficyt” sam w sobie nie wyklucza braku demokracji, raczej potwierdza jej istnienie, choć z niedoborem, może (a raczej na pewno) z wadami.

Główne pytania w tym opracowaniu brzmią więc następująco: jak wygląda demokracja bez narodu (tutaj na przykładzie demokracji na poziomie ponadnarodowym w UE)?, oraz jakie są źródła takiej demokracji, skoro źródłem nie jest naród, a obszarem występowania nie jest państwo? Świadomie pytanie o źródła demokracji jest postawione nie jako pierwsze, gdyż najpierw należy demokrację na poziomie ponadnarodowym zdefiniować, sprawdzić jej komponenty i przejawy, a dopiero - nieco przewrotnie - zastanowić się nad przyczynami generującymi tego typu demokratyczne rozwiązania.

Powyższe założenia wsparte teorią ponadnarodowości (supranationalism) określają przestrzeń badawczą sytuującą demokrację ponadnarodową poza państwem i zdeterminowaną brakiem narodu. Teoria ponadnarodowości, jako teoria specjalistyczna, lub pierwszego rzędu (first order theories) ${ }^{4}$ wydaje się niezwykle odpowiednim paradygmatem w procesie badania demokracji ponadnarodowej. Teoria ta wyjaśnia zarów-

2 Poziomy rozmyte nie są poziomami terytorialnymi i mają naturę epifenomenalną, co oznacza także, że tym samym nie są one bytami ontologicznymi, gdyż terytoria rozmyte nie istnieją realnie. Paradoks polega na tym, że na poziomach rozmytych lub pomiędzy nimi mogą działać realni aktorzy oraz realne instytucje.

3 Szerzej na ten temat: A. Moravcsik, In Defence of the Democratic Deficit. Reassessing Legitimacy in the European Union, ,Journal of Common Market Studies”, vol. 40, November 2002; A. Moravcsik, Deficyt demokracji - wyolbrzymiony problem, „Nowa Europa” 2005, nr 1(I), s. 278; G. Majone, Europe's Democratic Deficit. The Question of Standards, „European Law Journal”, nr 4, March 1996; K. A. Wojtaszczyk, J. Szymańska, Deficyt ..., op. cit. s. 15. K. A. Wojtaszczyk po pojęciem deficyt demokracji określa ,różnicę między formą sprawowania władzy w państwie członkowskim a systemem instytucjonalnym UE, w której w przeciwieństwie do państwa narodowego nie występuje klasyczny trójpodział władzy stanowiący charakterystyczną cechę ustroju demokratycznego".

4 Teorie pierwszego rzędu zajmują się wybranym obszarem zjawisk lub procesów, a więc nie pretendują do wyjaśniania całokształtu integracji europejskiej. Por. J. Ruszkowski, Teorie specjalistyczne w studiach europejskich, w: J. Ruszkowski, L. Wojnicz, Teorie w studiach europejskich. W kierunku nowej agendy badawczej, Szczecin-Warszawa 2012, s. 30; D. A. Lake, Theory is dead, long live theory: The end of the Great Debates and the rise of eclecticism in International Relations, „European Journal of International Relations” 2013, vol. 19(3), s. 567-587. Neil Nugent określa teorie, które dedykowane są wyjaśnianiu procesów np. tylko w UE jako middle range theories (teorie średniego zasiegu), N. Nugent, The Government and Politics of the EU, Durham 2006. Z kolei teorie drugiego rzędu (second order theories) są raczej zbiorami (zasobnikami) wielu innych podejść teoretycznych. 
no zjawisko funkcjonowania i przebiegu relacji ponadnarodowych, ale także proces i warunki ich powstawania. J. H. H. Weiler precyzyjnie zauważył, że „na poziomie społecznym i jednostkowym - nie państwowym - supranacjonalizm uosabia pewien ideał, który częściowo odbiera ważność państwowym aspektom narodowości (stanowiącej najpotężniejszy chyba wyraz tożsamości grupowej) jako podstawowemu punktowi odniesienia w transnarodowych relacjach międzyludzkich" (Weiler, 1995, s. 37-38). James G. March i Johan P. Olsen uważają, że ponadnarodowość jest systemem (lub sposobem) powiązania ponad granicami segmentów (podziałów państw, podziałów ich kompetencji, podziałów terytorialnych, podziałów interesów i ról itd.), bowiem ,,polityczny świat jest skonstruowany według mechanizmów rozczłonkowania. Koordynacja ponad granicami segmentów jest trudniejsza niż w obrębie granic. W różnych dziedzinach [segmentach - przyp. J.R.] odmienne zbiory reguł zwykle ewoluują niezależnie od siebie" (March, Olsen, 2005, s. 37). Należało stworzyć stabilne (podobne do siebie, powiązane) reguły działania nie w danym segmencie (dziedzinie), ale pomiędzy nimi i ponad nimi. „Oczywiście, w polityce występuje szczególnie zainteresowanie korzyściami związanymi z łączeniem obywateli o określonych potrzebach z agencjami, które w największym stopniu zajmują się ich zaspokajaniem. Koordynacja i zgodność w polityce umożliwiają funkcjonowanie systemów politycznych - choć nie zawsze są one wewnętrznie spójne" (March, Olsen, 2005, s. 37-38). Zachodzi tutaj umiędzynarodowienie władzy, czyli wyniesienie jej ze szczebla narodowego na szczebel międzynarodowy (także ponadnarodowy) za dobrowolną zgodą państw narodowych (Price, 2004, s. 23). W takim ujęciu może ukształtować się suprasystem, który będzie usytuowany ponad subsystemami ${ }^{5}$.

Teoria ponadnarodowości wyjaśnia nie tylko fenomen supranacjonalizmu czy szeroko pojętej przestrzeni ponadnarodowej (supranational space), ale odnosi się także do procesów tworzenia układów ponadnarodowych, relacji pomiędzy ponadnarodowymi aktorami oraz pomiędzy nimi a aktorami na innych poziomach itd. Jest to teoria, która odnosi się sekwencyjne do wielu ponadnarodowych rozwiązań oraz osiągnięć (ponadnarodowe prawo, ponadnarodowe procesy decyzyjne, ponadnarodowa demokracja itd.). Przestrzeń, w której zachodzą relacje pomiędzy aktorami usytuowanymi na poziomie ponad państwami (supra-state) de facto wynika z samej definicji ponadnarodowości, gdyż jest to przestrzeń ponadnarodowa i z reguły także ponadpaństwowa. W wertykalnym układzie stosunków międzynarodowych jest to przestrzeń występująca ponad poziomem relacji międzyrządowych (międzypaństwowych). Wpływ instytucji ponadnarodowych nie może być wyjaśniony wyłącznie w odniesieniu do preferencji państw członkowskich (Kassim, Menon, 2002, s. 6), ale także w odniesieniu do preferencji tych instytucji oraz ich ,przestrzennego" usytuowania ponad państwami.

Przestrzeń ponadnarodowa może być rozpatrywana przy zastosowaniu koncepcji przestrzeni fragmentarycznej (fragmented space) oraz przestrzeni wielowarstwowej (multi-layered space) ${ }^{6}$. Przestrzeń fragmentaryczna składa się z kilku równoległych

5 Por. relacje pomiędzy suprasystemami a subsystemami według J. G. Millera w: Living Systems, New York 1978.

${ }^{6}$ Por. zastosowanie tych koncepcji w odniesieniu do ruchów migracyjnych w: F.W. Riggs, Glocalization, Diasporas and Area Studies, 2001, s. 3, www2.hawaii.edu. 
elementów tworzących horyzontalną całość (można ją porównać do znanej w studiach europejskich koncepcji kręgów koncentrycznych). Z kolei przestrzeń wielowarstwowa składa się z kilku wertykalnych poziomów tworzących hierarchiczną strukturę zarządzania. W przestrzeni ponadnarodowej analizowana jest demokracja, która stanowi swoisty fenomen, tak jak fenomenem jest ponadnarodowość (Ruszkowski, 2010).

Teoria ponadnarodowości będzie paradygmatem służącym do podjętej analizy, ale w połączeniu z koncepcyjnymi elementami multi-level Governance oraz teorii demokracji, która jest swoistym punktem odniesienia i klasycznym odniesieniem w procesie wyjaśniania ${ }^{7}$. Należy przy tym zaznaczyć, że klasyczna teoria demokracji nie przewiduje rozwiązań demokratycznych na poziomie ponadnarodowym, więc bez wsparcia ze strony teorii ponadnarodowości nie byłaby paradygmatem wystarczającym.

\section{Komponenty terminologiczne demokracji ponadnarodowej}

Państwo narodowe nie jest już główną (a tym bardziej jedyną) areną występowania demokracji. W tym sensie także teoria demokracji nie może być stosowana jedynie w odniesieniu do państwa. W tej analizie badaniu poddana zostanie demokracja w Unii Europejskiej, ale tylko występująca na poziomie ponadnarodowym (z ewentualnymi niezbędnymi interakcjami $\mathrm{z}$ innymi poziomami $\mathrm{w}$ wielopoziomowym zarządzaniu w ramach UE).

W próbie definicji terminu ,demokracja ponadnarodowa” możemy wskazać na trzy grupy komponentów: 1) komponenty wyłączne (występujące tylko w tego typu demokracji); 2) komponenty wspólne (wstępujące zarówno w demokracji ponadnarodowej i w demokracji klasycznej (opartej na państwie), oczywiście z wyłączeniem tych, które cechują demokrację klasyczną, ale nie wstępują w demokracji ponadnarodowej, np. de$m o s)$; 3) substytuty (komponenty zastępujące w demokracji ponadnarodowej te, które występują w demokracji klasycznej, ale nie pojawiają się w takiej formie w demokracji ponadnarodowej).

\section{Komponenty wyłączne}

Komponenty wyłączne składające się na definicję demokracji ponadnarodowej siłą rzeczy mają charakter ekskluzywny, bowiem występują w tego typu demokracji, ale próżno szukać ich w klasycznym ujęciu tego zagadnienia i w klasycznej teorii demokracji. Oznacza to, że demokracja ponadnarodowa badana w odniesieniu do Unii Europejskiej wykształciła nowe formy rozwiązań i procesów demokratyzacyjnych.

Jeżeli przyjmiemy, że system polityczny Unii Europejskiej opiera się na wielopoziomowym zarządzaniu (Multi-Level Governance - MLG), wówczas demokracja ponadnarodowa będzie konglomeratem rozwiązań demokratycznych ulokowanych na poziomie ponadnarodowym, czyli ponad państwami członkowskimi i tym samym bez

${ }^{7}$ Szerzej por.: G. Sartori, Teoria demokracji, Warszawa 2006; H. Sosnowska, Wprowadzenie do teorii publicznego wyboru, Rzeszów 2000; I. Shapiro, Stan teorii demokracji, Warszawa 2006. 
możliwości ich udziału w takich rozwiązaniach, lub (i) poza państwami, ale w tym przypadku z możliwością ich partycypacji w procesach demokratycznych np. w wyborach do Parlamentu Europejskiego według ordynacji narodowych, a do tego - co istotne - ulokowanych poza konkretnym narodem. Możemy więc wskazać trzy parametry definicyjne, które sąjednocześnie komponentami lokalizacyjnymi i wyłącznymi determinantami demokracji ponadnarodowej w UE: 1) demokracja występuje ,ponad państwami”, 2) demokracja występuje „poza państwami”, 3) demokracja występuje poza konkretnym narodem (demos).

Pierwsza determinanta dotycząca demokracji ponadnarodowej ulokowanej ponad państwami członkowskimi nie dopuszcza możliwości udziału w niej państw członkowskich. Mamy tutaj do czynienia z efektem by-pass ${ }^{8}$, czyli z pominięciem państw zarówno na etapie kreacji takich rozwiązań demokratycznych, jak i na etapie ich praktycznej partycypacji. Pod pojęciem „,pomijanie” państw członkowskich w wielopoziomowym systemie zarządzania (MLG) Unii Europejskiej należy rozumieć przede wszystkim podejmowanie przez aktorów niepaństwowych (regionalnych, lokalnych, ponadnarodowych i ponad-ponadnarodowych) decyzji, działań, realizacji zadań oraz bezpośrednich kontaktów z pominięciem poziomu narodowego, czyli w praktyce bez udziału państw członkowskich oraz ich rządów. Pomijanie państw członkowskich UE (poziomu narodowego) jest najbardziej spektakularnym rodzajem pomijania w MLG, gdyż przynosi ono szczególne konsekwencje łącznie z przyczynianiem się do destatyzacji państw (niekoniecznie do ich desuwerenizacji). W pomijaniu poziomu narodowego mogą więc brać udział wyłącznie aktorzy niepaństwowi (non-state actors) ${ }^{9}$.

Efekt by-pass implikuje ponadto kolejny element specyficzny demokracji ponadnarodowej, jakim jest wymykanie się tego typu rozwiązań demokratycznych spod kontroli państw członkowskich. Wśród okoliczności sprzyjających wymykaniu się demokratycznych rozwiązań ponadnarodowych w UE spod kontroli państw członkowskich możemy zauważyć: 1) postępującą autonomizację instytucji ponadnarodowych, które takie rozwiązania tworzą lub (i) w nich partycypuja); 2) brak zgody pomiędzy państwami członkowskimi, nieporozumienia i wszelkiego rodzaju rozbieżności w ich stanowiskach $^{10}$.

Demokracja „,ponad państwami” jest więc najczystszą postacią demokracji ponadnarodowej (przykładem takiego rozwiązania może być Europejska Inicjatywa Obywatelska - EIO).

8 Efekt by pass jest widoczny przede wszystkim z perspektywy specjalistycznej teorii wielopoziomowego zarządzania (Multi-level Governance - MLG). Jest to najbardziej radykalne zjawisko w Unii Europejskiej, które w widoczny sposób redefiniuje rolę państw członkowskich w tej organizacji nie tylko poprzez przypadki jej ograniczenia, ale przede wszystkim poprzez przypadki wyłączenia państw z udziału w danym procesie lub zjawisku.

9 Pomijanie państw członkowskich w MLG w wyniku z działań aktorów ponadnarodowych, ponad-ponadnarodowych, transnarodowych, regionalnych i lokalnych pozwala tym aktorom zwiększać swój wpływ poprzez samodzielne, bezpośrednie i często niezależne działania, a także poprzez rozwój zakresu ich władzy, w zwrotnym efekcie także wobec pominiętych państw członkowskich. Por. J. Ruszkowski, Struktura wielopoziomowego zarzadzania w Unii Europejskiej, w: Multi-level Governance w Unii Europejskiej, red. J. Ruszkowski, L. Wojnicz, Szczecin-Warszawa 2013.

${ }_{10}$ Abstrahując od przyczyn braku takiej kontroli (wynikających z regulacji prawnych, zaniechania czy też właśnie ze wspomnianego już braku zgodności pomiędzy państwami członkowskimi). 
Druga determinanta dotycząca demokracji ponadnarodowej tym razem ulokowanej „poza państwami”, dopuszcza możliwość udziału w niej państw. Państwa w różnym zakresie partycypują w takiej demokracji, choć rozstrzygane kwestie ich nie dotyczą. Przykładem partycypacji państw w demokracji ,poza państwami” mogą być referenda dotyczące Traktatu ustanawiającego Konstytucję dla Europy czy też narodowe ordynacje wyborcze, według których odbywają się wybory do Parlamentu Europejskiego (oczywiście poza pewnym wspólnym katalogiem minimalnych wymogów ordynacyjnych, które muszą być stosowane w każdym kraju członkowskim). Demokracja ,poza państwami” jest wciąż demokracją ponadnarodowa, ale nie jest ona jej czystą postacią ze względu na możliwość partycypacji państw członkowskich.

Trzecia determinanta dotycząca demokracji ponadnarodowej ulokowanej poza konkretnym narodem (demos) oznacza, że źródłem takiej demokracji i suwerenem nie jest demos, czyli populacja, która identyfikowałaby się z UE, lecz inne podmioty sprawcze (państwa członkowskie, instytucje europejskie, społeczeństwo europejskie).

Wszystkie trzy determinanty występują na poziomie ponadnarodowym w UE, zatem odnoszą się do demokracji ponadnarodowej i sąjej ekskluzywnymi komponentami definicyjnymi.

\section{Komponenty wspólne}

Komponenty wspólne występują w demokracji klasycznej oraz w demokracji ponadnarodowej i tym samym w pewien sposób legitymizują demokrację ponadnarodową. Do tych komponentów zaliczyć można przede wszystkim: suwerenność, legitymizację oraz partycypację.

Suwerenność nie jest jedynie wyłącznym przywilejem terytorialnego państwa narodowego w rozumieniu westfalskim, bowiem może ona mieć charakter zdeterytorializowany i pojawić się także w podmiotach międzynarodowych, w tym mających charakter ponadnarodowy ${ }^{11}$.

Unia Europejka posiada suwerenność zewnętrzną i wewnętrzną. Pierwsza polega na tym, że jej władze nie są zależne od innych władz organizacji międzynarodowych lub państw nieczłonkowskich. Ponadto UE reguluje swoje sprawy bez zewnętrznej ingerencji. Suwerenność wewnętrzna opiera się z kolei na regulacjach traktatowych oraz uznaniu istnienia UE przez kraje członkowskie. Tym samym do tych ustaleń dodać musimy wewnętrzne i zewnętrzne uznanie podmiotowości UE. Wewnętrzne uznanie odnosi się do legitymizacji UE przez państwa członkowskie oraz w pewnych zakresach przez obywateli UE, a zewnętrzne odnosi się do uznania podmiotowości UE przez inne organizacje międzynarodowe i państwa nieczłonkowskie (Hurrelmann, 2014, s. 89).

11 Szerzej na temat suwerenności: J. Czaputowicz, Suwerenność, Warszawa 2013, s. 19-21. Zob. także: A. Marszałek, Suwerenność a integracja europejska w perspektywie historycznej. Spór o istote suwerenności i integracji, Łodź 2000. 
Drugim komponentem wspólnym jest legitymizacja, którą można sklasyfikować jako funkcję określonej koncepcji demokracji oraz integruje ideę państwa prawa i praw człowieka w jednym systemie (np. politycznym). Andrew Moravcsik uważa, że obiegowe twierdzenie, jakoby w „UE nie ma legitymizacji demokratycznej nie znajduje dostatecznie przekonujących dowodów. Konstytucyjna kontrola i równowaga, pośrednia kontrola demokratyczna sprawowana przez rządy krajowe i coraz większe uprawnienia Parlamentu Europejskiego sprawiają, że polityka UE w niemal wszystkich dziedzinach jest jasna, transparentna, skuteczna i odpowiadająca potrzebom obywateli Europy. Większość krytyków nie dostrzega tego względnie optymistycznego wniosku, dokonując porównania między UE a utopijną formą demokracji deliberatywnej” (Moravcsik, 2005, s. 278).

Demokratyczna legitymizacja wymaga przede wszystkim większej partycypacji obywateli. Legitymizacja wspólnoty ponadnarodowej jest definiowana nie w sensie niezależności, ale poprzez stałe odniesienie do narodowej praktyki. Takie odnoszenie do narodowej praktyki służy do ostatecznego zdefiniowania odmiennych ponadnarodowych standardów legitymizacji (Kumm, 2005, s. 13 i 38).

Legitymizacja w demokracji ponadnarodowej bazuje na trzech odmiennych wartościach: 1) demokracji (wymaga publicznej odpowiedzialności i ochrony praw jednostki), 2) integracji (poszukuje zinstytucjonalizowanych rozwiązań transnarodowego mechanizmu podejmowania decyzji)) 3. autonomii państw członkowskich (utrzymanie narodowej różnorodności). Według W. Wallace’a i J. Smitha jest to triangularna koncepcja legitymizacji UE, która odzwierciedla przeciwności pomiędzy interesem międzyrządowym, funkcjonalną administracją a demokracją, która jest osadzona w Traktatach Założycielskich Wspólnot Europejskich. Taka legityzmizacja może być rozwijana przy zachowaniu równowagi pomiędzy wartościami demokratycznego zarządzania, efektywną integracją oraz narodową autonomią (Wallace, Smith, 1995, s. 140). Konieczne jest zaistnienie equilibrium w triangularnym modelu W. Wallace'a i J. Smitha. To zestawienie sprzyja także legitymizacji systemu UE, w którym Rada Unii Europejskiej jest strażniczką narodowej autonomii, Parlament Europejski jest strażnikiem demokratycznego zarządzania, a Komisja Europejska wraz z Europejskim Trybunałem Sprawiedliwości są technokratycznymi strażnikami efektywnej integracji (Wallace, Smith, 1995, s. 141).

Podmiotami legitymizującymi demokrację w UE są obywatele UE oraz państwa członkowskie. Jak twierdzi Maria Kruk, „ta dualistyczna legitymacja wskazuje na złożony charakter Unii. Z jednej strony jest ona związkiem państw, z drugiej - zbudowana jest $z$ woli obywateli. Po wprowadzeniu obywatelstwa europejskiego są to niewattpliwie obywatele europejscy, ale chyba stąd daleko jeszcze do określenia ich mianem suwerena" (Kruk, 2004, s. 44). Tego typu podwójna legitymizacja jest fakultatywna, bowiem dostarczana przez państwa narodowe będące dobrowolnymi członkami UE (reprezentowanymi przede wszystkim w Radzie UE oraz w Radzie Europejskiej), ale także przez obywateli UE i bezpośrednio wybierany przez nich Parlament Europejski (uważany za strażnika kapitału legitymizacyjnego). Legitymizacja demokracji w UE nie opiera się na podmiocie zbiorowym, jakim jest naród, ale na pluralistycznym obywatelstwie tworzącym coś na wzór wielonarodowego civitas (Wessels, Diedrichs, 1996, s. 4). 
Legitymizacja poprzez państwa członkowskie wypływa z demokratycznego charakteru tych państw, ponieważ utrzymują one decydujący wpływ na proces podejmowania decyzji w ramach struktury instytucjonalnej UE oraz transferując (delegując) via traktaty rozwiązania demokratyczne na poziom UE świadomie współtworzą demokrację w UE.

Legitymizacja poprzez obywateli $\mathrm{UE}^{12}$ ogniskuje się w dobrowolnym transferze ich lojalności na instytucje UE, w tym przede wszystkim na Parlament Europejski poprzez akt wyborczy.

Według Tanji Börzel, w Unii Europejskiej można wskazać na dwa całkiem inne typy legitymizacji. Pierwszy typ to słaba legitymizacja input, która wynika z partycypacji państw, które jednak są w pewnych sytuacjach albo pomijane, albo pozbawione zdolności do działania na niektórych obszarach integracji wewnątrz UE (np. na rynku wewnętrznym, czy też w polityce pieniężnej w ramach obszaru euro). Drugi typ to legitymizacja output, która dotyczy skuteczności decyzyjnej UE, choć przez długi czas zauważalne było pozbawienie obywateli UE wpływu na mechanizm podejmowania decyzji. Zresztą pierwsza legitymizacja jest wykorzystywana do kompensacji drugiej. Wyjściem z tej pułapki byłoby - jak sądzi Börzel - zastosowanie w UE modelu federalizmu kooperacyjnego na wzór Niemiec ${ }^{13}$. Obecnie można zauważyć, że legitymizacja input została wzmocniona poprzez przesunięcie obywateli UE (których organem przedstawicielskim jest Parlament) bliżej procesu decyzyjnego ${ }^{14}$. Przykładem takiego przesunięcia jest Europejska Inicjatywa Obywatelska. Tym samym mamy do czynienia ze swoistą legitymizacją bezpośrednią, która zakłada wprost włączenie obywateli do procesu decyzyjnego.

Trzecim komponentem wspólnym w definicji demokracji ponadnarodowej jest partycypacja obywateli. Faktem pozostaje, że jest ona słabym elementem demokracji w $\mathrm{UE}^{15}$, to jednak istnieją obszary, w których jest ona widoczna (np. bierne i czynne prawo wyborcze w wyborach do Parlamentu Europejskiego, Europejska Inicjatywa Obywatelska, europejskie organizacja pozarządowe, referenda w sprawie Traktatu ustanawiającego Konstytucję dla Europy). W obecnych rozwiązaniach demokratycznych dostrzegamy zarówno partycypację bezpośrednią, której sztandarowym przykładem jest Europejska Inicjatywa Obywatelska oraz wybory do PE, oraz partycypację pośrednią realizowaną np. poprzez europartie lub przez europejskie mass media (Ruszkowski, 2007). Partycypacja bezpośrednia dowodzi, że demokracja ponadnarodowa w UE posiada rozwiązania demokracji partycypacyjnej, a nie tylko demokracji przedstawicielskiej.

12 Szerzej na ten temat zob.: R. Arnold, The Different Levels of Constitutional Law in Europe and Their Interdependence, w: J. Nergelius, P. Policastro, K. Urata, Challenges of Multi-Level Constitutionalism, Kraków 2004, s. 107.

13 Według tego scenariusza Rada UE musi stać się drugą izbą Parlamentu Europejskiego, a sam Parlament powinien stać na równi z Radą w procesie decyzyjnym. Z kolei Komisja Europejska powinna stać się efektywnym rządem, niezależnym od państw członkowskich.

14 Tego typu rozważania T. Börzel zaprezentowała w opracowaniu pt. What can Federalism teach us about the European Union? The German Experience, www.riia.org/pdf/research/europe.Borzel/pdf.

${ }^{5}$ Przykład partycypacji obywateli jest doskonałym w badaniach deficytu demokracji, gdyż w UE nie ma wprost gwarancji reprezentowania interesów obywateli. 


\section{Substytuty}

Substytuty w demokracji ponadnarodowej to komponenty zastępujące te, których nie można zidentyfikować w takiej demokracji. Wskażmy na substytuty trzech istotnych elementów w demokracji ponadnarodowej, czyli narodu, odpowiedzialności przed narodem oraz demokratycznej reprezentacji politycznej.

Zaczynając od substytutu narodu zauważmy, że to właśnie ,demos jest warunkiem demokracji. [...]. Skoro nie ma demos, nie może być - z założenia - ani demokracji ani demokratyzacji Europy. [...]. Istnieją dwie wersje tezy o braku europejskiego demos. 'Miękka' wersja Federalnego Trybunału Konstytucyjnego w Niemczech (Bundesverfassungsgericht - BVG) to wersja, którą można nazwać 'jeszcze nie': wprawdzie nie ma na razie demos, ale nie wyklucza się a priori możliwości jego zaistnienia [...]. 'Twarda' wersja nie tylko zupełnie odrzuca taką możliwość jako obiektywnie nierealną, ale odrzuca ją także jako niepożądaną: uważa się, że integracja nie ma polegać na stworzeniu nowego narodu czy ludu Europy, ale na bardzo bliskiej Unii między ludźmi w Europie" (Weiller, 2005, s. 77) ${ }^{16}$. Nie istnieje naród europejski, ale są narody państw europejskich. Wprowadzenie prawnie sformalizowanego obywatelstwa Unii Europejskiej, które jest wyrażone za pośrednictwem obywatelstwa państw członkowskich UE, nie jest w stanie stworzyć narodu unijnego w sensie politycznym. Zatem ponadnarodowej demokracji europejskiej brakuje podmiotu sprawczego, jakim byłby europejski naród.

Można oczywiście w sposób klasyczny założyć, że jeżeli nie istnieje demos, to jednocześnie nie ma demokracji. Teza o braku narodu europejskiego odnoszona do Unii Europejskiej (no demos thesis), choć jest prawdziwa, to jednak nie oznacza automatycznie braku demokracji.

Substytutem narodu europejskiego $(\text { demos })^{17} \mathrm{w}$ Unii Europejskiej jest społeczeństwo europejskie. Brak niezbędnego podmiotu procesu demokratycznego, czyli desygnatu nazwy zbiorowej ,naród”, który mógłby się sam ukonstytuować jako naród obywatelski wygenerował krytykowaną na gruncie pojęć i empirii tezę o braku narodu europejskiego (no-demos-thesis). Jednak można mówić o społeczeństwie obywatelskim Europy (civil society), bowiem ,cechą wyróżniającą civil society jest uznanie praw człowieka za prawa podstawowe. To właśnie równość obywateli wobec prawa

16 Weiler odnosi się także do ewentualnych szans na powstanie europejskiego demos. Posługuje się przy tym opinią Alexisa de Tocqueville'a, który stwierdził, że społeczeństwo Ameryki Północnej utworzone ze wszystkich narodów świata [...], jednym słowem społeczeństwo bez korzeni, bez wspomnień może zmienić się w lud, opierając się na przestrzeganiu wartości takich jak: demokracja, samorządność, równość itp., które znajdujemy w amerykańskiej konstytucji, A. de Tocqueville, Listy, wybór, wstęp i opracowanie I. Grudzińksa-Gros, Kraków 1999, s. 57, cyt. za: J. H.H. Weiler, Czy Europa..., op. cit., przypis 52, s. 128. Narodziny narodu amerykańskiego mogą posłużyć za pewien model powstania demos z wielu różnych i specyficznych ethnos. Zatem demos nie musi koniecznie wiązać się z jedną przynależnością narodową.

17 Narodu obywatelskiego nie należy mylić z przedpolityczną wspólnotą losu, uformowaną przez wspólne pochodzenie, język i historię. W ten sposób pomija się woluntarystyczny charakter narodu obywatelskiego, którego zbiorowa tożsamość wywodzi się z demokratycznego procesu. Zatem najpierw musi pojawić się demokratyzacja, a dopiero potem tożsamość zbiorowa, która nie istnieje niezależnie. J. Habermas, Czy Europie potrzebna jest Konstytucja?, „Nowa Europa” 2005, nr 1, s. 53. 
i efektywnie przeprowadzony podział władzy w UE (separation of powers) odróżnia civil society od repressive socjety (Böckenförde, 1994, s. 75). Zatem istnieje europejskie civic (wspólnota równych sobie obywateli mogąca rozszerzać się na innych ludzi zamieszkujących dane terytorium), ale nie ma europejskiego ethnic (naród tworzący pierwotny kolektyw jednostek o cechach partykularnej i jednorodnej wspólnoty, która nie rozszerza się na innych ludzi [nie obejmuje nowych ludzi z zewnątrz] bowiem jest ograniczona do swojej etniczności).

Polityczne konstrukcje, takie jak Unia Europejska mogą posiadać swoje civic, których członkowie mają świadomość udziału w określonej przestrzeni publicznej. Geograficznie tę przestrzeń publiczną wyznacza Europa oraz jej najbliższe sąsiedztwo. „Przynależność cywilizacyjna odgrywa bardzo istotną rolę w funkcjonowaniu systemów społecznych. Polega ona na określeniu się człowieka nie tylko wobec grupy czy społeczności, które mogą ulec rozbiciu w efekcie podboju, eksploatacji, czy dominacji, lecz także w stosunku do szerszej wspólnoty ludzi uznających te same wartości." (Kieniewicz, 2004, s. 88).

Brak europejskiego demos i ethnic jest oczywisty, ale za to istnienie europejskiego społeczeństwa obywatelskiego (civic) pozwala go skojarzyć z przestrzenią publiczna, nawet typu partykularnego i o ograniczonym do Unii Europejskiej zasięgu.

$\mathrm{Z}$ kolei substytutem braku bezpośredniej odpowiedzialności przed narodem jest w demokracji ponadnarodowej odpowiedzialność pośrednia przed Parlamentem Europejskim oraz przed Trybunałem Sprawiedliwości Unii Europejskiej. W Unii Europejskiej można zauważyć, choć nie w klasycznej formie, pewne zastępcze komponenty odpowiedzialność horyzontalnej (horizontal accountability) pomiędzy władzą ustawodawczą, wykonawczą i sądowniczą. Występuje ona raczej w substytutowej formie pomiędzy instytucjami, które są do tych władz zbliżone (Komisja Europejska, Parlament Europejski, Rada UE itd.) lub, które wprost takie władze reprezentują (Trybunał Sprawiedliwości jest w UE władzą sądowniczą). Włączenie do tej odpowiedzialności technokratycznej kontroli sprawowanej przez Parlament Europejski, Trybunał Sprawiedliwości UE, Trybunał Obrachunkowy, Europejskiego Rzecznika Praw Obywatelskich, czy OLAF oraz duża rola elit i ekspertów (tzw. epistemic communities), pozwalają stwierdzić, że substytutem odpowiedzialność horyzontalnej może być w UE odpowiedzialność technokratyczna ${ }^{18}$.

18 Istotnym elementem demokracji jest także odpowiedzialność wertykalna (vertical accountability), czyli odpowiedzialność polityków przed obywatelami, którzy ich wybrali. W Unii Europejskiej trudno znaleźć wprost symptomy tego typu odpowiedzialności, gdyż pomimo, że wszyscy obywatele UE mogą wybierać posłów do Parlamentu Europejskiego w wyborach powszechnych, równych i tajnych, to jednak odpowiedzialność posłów do PE przed swoimi wyborcami praktycznie nie istnieje. To jest kadłubowe rozwiązanie demokratyczne, gdyż akt wyborczy jest w pełni demokratyczny, ale późniejsze egzekwowanie odpowiedzialności w przestrzeni publicznej już takim nie jest. Szerzej na temat odpowiedzialności horyzontalnej i wertykalnej zob.: G. O’Donnell, Horizontal Accountability in New Polyarchies, ,Journal of Democracy”, vol. 9, nr 3, July 1998; Reflecting on uneven democracies: The Legacy of Guilermo O'Donnel, eds. D. M. Brinks, M. Leiras, S. Mainwaring, Baltimore, Maryland, John Hopkins University Press, 2014; Odpowiedzialność w Unii Europejskiej. Rzeczywistość czy iluzja?, red. A. Sroka, Warszawa 2011. 
Należy pamiętać, że w wielopoziomowym systemie politycznym Unii Europejskiej odpowiedzialność jest rozmyta pomiędzy różne poziomy oraz pomiędzy różnych aktorów operujących na tych poziomach i pomiędzy nimi. Według A. Hurrelmann, problemem jest także to, że UE ,zajmuje się sprawami, którymi obywatele państw członkowskich mało się interesują m.in. dlatego, że decyzje podejmowane przez instytucje UE są głównie o charakterze regulacyjnym, a mniej o charakterze dystrybucyjnym (lub z małym efektem dystrybucyjnym) (Hurrelman, 2014, s. 88). Należy jednak dodać, że w zakresie polityki regulacyjnej, kwestie, którymi zajmuje się UE mogą bardzo interesować obywateli UE, gdyż wpływają na ich codzienne życie (np. kwestia rejestracji samochodów z kierownicą po prawej stronie, czy wycofanie z obiegu żarówek analogowych). Nie zmienia to faktu, że model regulacyjny posiada bardziej charakter funkcjonalny nie przyczynia się w jakiś szczególny sposób do rozwoju procesu demokratycznego.

„Jedynym mechanizmem demokratycznego pociagania do odpowiedzialności dostępnym w ramach struktur unijnych jest Europejska Inicjatywa Obywatelska (European Citiens' Initiative - ECI), w ramach której można zażądać od Komisji Europejskiej dokonania oficjalnego przeglądu istniejącego ustawodawstwa, pod warunkiem zebrania wśród obywateli UE miliona deklaracji poparcia w przeciagu roku (podpisy muszą pochodzić z co najmniej 7 państw członkowskich UE przy spełnieniu minimalnej ilości deklaracji określonej dla poszczególnych krajów) (Hilary, 2015, s. 31).

W przypadku substytutu demokratycznej reprezentacji politycznej w Unii Europejskiej zauważamy zamiennik zhierarchizowanego układu instytucji, które w demokracji klasycznej cechują taką reprezentację w państwie narodowym (w uproszczeniu: demokratyczny samorząd, partie polityczne, demokratyczny rząd, demokratyczny parlament). W Unii Europejskiej nie ma samorządu i nie ma rządu generowanego w wyniku demokratycznych wyborów. Jednak w UE reprezentacją regionów mogą być ich przedstawicielstwa przy UE lub Komitet Regionów. Z kolei w przypadku tworzenia rządu przez partię polityczną, która zwyciężyła w demokratycznych wyborach, absolutnie nieekwiwalentnym substytutem jest desygnowanie na Przewodniczącego Komisji Europejskiej kandydata z grupy politycznej, która wygrała w wyborach do Parlamentu Europejskiego. Takie rozwiązanie można jedynie uznać za pierwszy krok do pełnego uzależnienia od wyników wyborów do PE procesu powołania całej Komisji Europejskiej. Kolejny element reprezentacji politycznej, jakim są partie polityczne odzwierciedlają grupy polityczne w Parlamencie Europejskim oraz partie na poziomie europejskim (tzw. europartie). Badacze dostrzegają nawet zręby systemu partyjnego w UE, ale tego typu dywagacje zasługują na odrębne opracowania. Ostatni element owej reprezentacji jest w UE niemal ekwiwalentny do demokracji klasycznej, gdyż Parlament Europejski jest reprezentacją demokratyczną, choć z pewnymi ograniczeniami w zakresie odpowiedzialności.

Oczywiście demokracja ponadnarodowa posiada także liczne braki nie rekompensowane substytutami (poza wspomnianym już brakiem demos, czy odpowiedzialności wertykalnej jest to np. brak europejskich kampanii wyborczych ${ }^{19}$, brak liderów wybie-

19 W tym obszarze były już pewne symptomy zmian. Przykładem może być kampania wyborcza partii Libertas z przywództwem Declana Ganleya. 
ranych przez obywateli, w tym przypadku poza posłami do PE, czy też dominacja instytucji niewiększościowych tzn. nie wybieranych w demokratycznych wyborach,

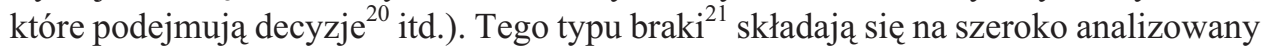
w literaturze deficyt demokracji w UE, który - jak już wspomniano - nie jest przedmiotem tego opracowania.

\section{3.Źródła demokracji ponadnarodowej}

Brak europejskiego demos wywołuje pytanie o źródła demokracji ponadnarodowej w Unii Europejskiej. Skoro demos jest głównym źródłem demokracji klasycznej, to oznacza, że w UE muszą istnieć inne źródła demokracji ponadnarodowej. Determinantą wpływającą na powstanie innych niż demos źródeł demokracji ponadnarodowej jest obiektywny fakt braku europejskiego narodu, bowiem z natury Unia Europejska jest wielonarodowa i wieloetniczna. Skąd więc biorą się rozwiązania demokratyczne w UE?

Bez wątpienia istotnym generatorem rozwiązań demokratycznych i demokracji będącej efektem finalnym są procesy demokratyzacyjne rozumiane jako wieloetapowe rozwiązania sprzyjające stopniowemu dochodzeniu do demokracji, w tym: 1) poszukiwanie i budowanie rozwiązań demokratycznych, 2) podążanie za nimi, 3) doprowadzenie do efektywnego osiagnnięcia demokracji. Dla nas istotne jest, że procesy demokratyzacyjne $\mathrm{z}$ jednej strony same są źródłami inicjującymi rozwiązania demokratyczne i budującymi demokrację, ale z drugiej strony są generatorami innych źródeł demokracji ponadnarodowej.

W odniesieniu do Unii Europejskiej możemy wskazać na kilka typów demokratyzacji: demokratyzacja przez państwa, demokratyzacja przez obywateli, demokratyzacja przez instytucje, demokratyzacja przez prawo, demokratyzacja przez aksjologię.

\section{Demokratyzacja przez państwa}

Głównym zabiegiem mogącym przyczyniać się do demokratyzacji Unii Europejskiej przez państwa członkowskie jest delegowanie przez nie kompetencji z poziomu narodowego na poziom UE, które odbywa się przede wszystkim poprzez traktaty (założycielskie oraz ich rewizje). Tego typu delegowanie jest przykładem procesów europeizacyjnych typu bottom-up (z dołu do góry).

Rosnące konsekwencje decyzji podejmowanych w Unii Europejskiej wywoływały liczne rewizje traktatów założycielskich, które ukierunkowane były wyraźnie na demokratyzację systemu politycznego UE (np. wzrost roli Parlamentu Europejskiego w Traktacie z Lizbony). Rewizje traktatów pozostają domeną państw członkowskich

${ }^{20}$ Np. Przewodniczący Rady Europejskiej czy Wysoki Przedstawiciel ds. Zagranicznych i Polityki Bezpieczeństwa.

${ }^{21}$ Dla ortodoksyjnych zwolenników tezy o deficycie demokracji w UE składają się na nią nie tylko braki, ale także substytuty. 
i najczęściej poprzedzone są albo Konferencją Międzyrządową (Intergovernmental Conference - IGC), albo konwentem (dwukrotnie w sprawie Karty Praw Podstawowych oraz w kwestii Konstytucji dla Europy). Konferencje Międzyrządowe oraz konwenty są zatem źródłami demokracji ponadnarodowej w procesie demokratyzacji przez państwa.

Delegowanie przez państwa członkowskie kompetencji (zadań, działań, funkcji, odpowiedzialności itd.) na poziom Unii Europejskiej odbywa się na podstawie regulacji zezwalających na taki zabieg zawartych najczęściej w konstytucjach narodowych. Z tego względu konstytucje państw członkowskich należy także uznać za źródło demokracji ponadnarodowej.

Demokracja ponadnarodowa w wyniku procesu europeizacji top down (odwrotnego wobec europeizacji bottom-up) potraf także reorganizować funkcje państw narodowych.

\section{Demokratyzacja przez obywateli}

Obywatelstwo Unii Europejskiej (EU Citizenship) ${ }^{22}$ nie ma charakteru państwowego i dlatego wnosi swoisty, raczej innowacyjny wkład do demokratyzacji systemu politycznego UE. Idea obywatelstwa europejskiego została ukształtowana w ramach Wspólnot Europejskich w wyniku napięcia pomiędzy drogą ich rozwoju opartą o ponadnarodowość z jednej strony i podejściem międzyrządowym z drugiej, łącząc przy tym konkretne prawa zawarte w istniejących traktatach założycielskich z ogólną ideą wspólnej tożsamości (Welsh, 1993, s. 1).

T. H. Marshal definiuje obywatelstwo UE jako symbol egalitaryzmu, bowiem wszyscy, którzy posiadają takie obywatelstwo będąc członkami danej wspólnoty, cieszą się de jure, a nawet de facto równością w odniesieniu do przysługujących im praw i obowiązków (Marshal, 1964, s. 92). Obywatele Europy mają wykazywać szczególne zainteresowanie Europą. Nie tylko rządy, partie polityczne i parlamenty, ale także społeczeństwo obywatelskie, partnerzy społeczni, intelektualiści torują drogę do ukształtowania europejskiej opinii publicznej oraz edukacji w zakresie demokracji

22 Prace nad obywatelstwem europejskim formalnie rozpoczęły się 26 czerwca 1984 r. kiedy to Rada Europejska obradująca w Fontainebleau powołała specjalny Komitet ad hoc ds. Europy Obywateli (Komitet składał się z przedstawicieli szefów państw i rządów krajów członkowskich oraz przewodniczącego Komisji Europejskiej. Na jego czele stanął Pietro Adonnino, były deputowany do Parlamentu Europejskiego, dlatego też mówiono wręcz o Komitecie Adonnino), który miał opracować działania prowadzące do wzmocnienia tożsamości Wspólnot Europejskich, a w konsekwencji wyjść naprzeciw oczekiwaniom narodów. W 1985 r. Komitet złożył dwa sprawozdania. W pierwszym proponował: uproszczenie kontroli granicznych, wprowadzenia nowych zwolnień od podatków dla książek i czasopism, wprowadzenie powszechnego systemu uznawalności dyplomów oraz porównywalność prawa pobytu. W drugim sprawozdaniu Komitet Adonnino skoncentrował się przede wszystkim na: prawach obywateli, sprawach socjalnych oraz ochronie zdrowia, a także na tożsamości europejskiej. Das Europäische Parlament und die Tätigkeit der Europäischen Gemeinschaft. Kurzdarstellungen, Europäische Parlament Generaldirektion Wissenschaft, 1988, De III/V, s. 1. Każda osoba posiadająca obywatelstwo państwa członkowskiego staje się obywatelem Unii. Obywatelstwo Unii uzupełnia, a nie zastępuje obywatelstwa narodowego. Oba obywatelstwa świadczą o istnieniu obywatelstwa wielopoziomowego (na poziomie narodowym i na poziomie ponadnarodowym). 
(Dastoli, 2001, s. 58). Jeżeli takie zainteresowanie Europą przekłada się na udział obywateli UE w wyborach do Parlamentu Europejskiego lub w Europejskiej Inicjatywie Obywatelskiej, to źródłem demokracji ponadnarodowej w procesie demokratyzacji przez obywateli jest ich wola oraz świadomość podejmowanych takich działań.

Obywatelstwo Unii Europejskiej jest także typem obywatelstwa formalnego (cechującego przynależność do struktury politycznej ${ }^{23}$ ), a nie obywatelstwa materialnego (cechującego przynależność do narodu) (Weiler, 1995, s. 30-31). „Obywatelstwo postnarodowe jest alternatywą restrykcyjnego pojęcia narodowości. O istocie tego obywatelstwa ma decydować fakt, że nie może ono być określone ani kwestią narodzin czy narodowości, lecz miejscem zamieszkania. W przeciwieństwie do narodowości obywatelstwo nie powinno znajdować odzwierciedlenia w kulturze narodowej państwa. Obywatelstwo UE ma charakter międzynarodowy i ponadnarodowy, wznosi się ponad partykularne założenia kultury i narodowości. Nie jest ono tylko zasadą polityczno-prawną, lecz także uznaniem praw społecznych.” (Delanty, 1999, s. 212-213). Zatem obywatelstwo UE z jednej strony wywodzić należy z prawa ziemi (ius soli), bowiem warunkiem jego otrzymania jest zamieszkiwanie w państwie członkowskim UE, ale z drugiej strony samo zamieszkiwanie w państwie członkowskim nie wystarczy. Należy być bowiem obywatelem kraju członkowskiego $\mathrm{UE}^{24}$. Więc obywatelstwo UE wywodzi się z drugiego prawa, jakim jest ius civis). W efekcie można stwierdzić, że obywatelstwo UE wynika z obywatelstwa narodowego. „Obywatelstwo postnarodowe nie może być pojmowane jedynie jako formalne prawo konstytucyjne. Posiada ono także wymiar niezależny, który upoważnia obywateli do korzystania z prawa uczestnictwa w życiu politycznym. W tym aspekcie różni się zasadniczo od obywatelstwa narodowego, które ma charakter czysto formalny. Takie właśnie formalne pojęcie obywatelstwa jest niebezpieczne, gdyż pozostawia otwarte pole dla ideologii populizmu. Obywatelstwo powinno być ostateczną podstawą legitymizacji budowania struktur instytucjonalnych, a nie dwuznacznych tożsamości kulturowych. Ważne jest, by wiązało się ono z uczestnictwem w tworzących się, nowych instytucjach politycznych." (Delanty, 1999, s. 213). Obywatelstwo polityczne jest integralną oraz centralną częścią tożsamości kulturowej.

Obywatelstwo UE jest zatem silnie kosmopolityczne, bowiem ma postnarodowy i ponadnarodowy charakter (Habermas, 1992, s. 8-10) i niesie za sobą określone uniwersalistyczne prawa. Idąc dalej wraz z włączeniem Karty Praw Podstawowych do Traktatu lizbońskiego obywatelstwo UE nabrało także charakteru obywatelstwa o parametrach konstytucyjnych demokratyzujących system polityczny $\mathrm{UE}^{25}$.

23 O ile obywatelstwo w rozumieniu klasycznym wiąże się tak z prawami, jak i obowiązkami, to obywatelstwo Unii Europejskiej cechują praktycznie tylko prawa przy jednoczesnej absencji obowiązków. Ten kto w Europie chce postrzegać siebie jako obywatela zarówno państwa członkowskiego, jak i Europy, ten powinien uznać wzmocnienie swojej podległości wobec Europy, w której prawo prywatne staje się ważną częścią prawa europejskiego.

24 Nie wszyscy zamieszkujący kraje członkowskie UE są ich obywatelami. Np. w Estonii duża mniejszość rosyjska nie posiada obywatelstwa estońskiego, zatem nie posiada tym samym obywatelstwa UE.

25 Obywatele państw członkowskich Wspólnot Europejskich po raz pierwszy otrzymali prawo wyborcze w 1979 r. w bezpośrednich wyborach do Parlamentu Europejskiego. Z kolei Traktat o Unii 
Obywatelstwo UE nie jest usytuowane na bazie narodowej lub etnicznej, ale na zobowiązaniu wobec ponadnarodowej i ponadpaństwowej wspólnoty politycznej. Ono legitymizuje taką wspólnotę, która tym samym staje się także wspólnotą obywateli, czyli autonomicznych i wolnych jednostek. Takie zobowiązanie wobec wspólnoty politycznej i wspólnoty obywateli jest kolejnym źródłem demokracji ponadnarodowej w procesie demokratyzacji przez obywateli. Wspólnota obywateli UE ma charakter otwarty, gdyż poszerza się o nowe jednostki należące do narodów, których państwa zostały przyjęte do UE, oraz charakter kosmopolityczny, gdyż jest ponadnarodowa i uniwersalistyczna. Przeciwnie do niej, wspólnota obywateli danego narodu ma charakter zamknięty i bardziej ksenofobiczny (bowiem wspólnota narodowa jest etniczna lub wieloetniczna, więc przede wszystkim z tego powodu ma charakter zamknięty).

\section{Demokratyzacja przez instytucje}

Zarówno wspominana już instytucja obywatelstwa europejskiego, jak i cały kompleks infrastruktury instytucjonalnej Unii Europejskiej skierowanej na ochronę praw jednostki (np. Trybunał Sprawiedliwość UE, Europejski Rzecznik Praw Obywatelskich, Europejska Agencja Praw Podstawowych Parlament Europejski (Dobrobyt, 2005, s. 157), Parlament Europejski itd., nakazują potwierdzić, że w UE budowana jest „Europa obywateli” (Europe of Citizens), na której bazuje ponadnarodowa demokracja. Jest to także dowód na dalszą instytucjonalizację zagadnienia znajdującego dotąd podstawę kodyfikacyjną w Karcie Praw Podstawowych. Wspomniane instytucje są źródłami demokracji ponadnarodowej w procesie demokratyzacji przez instytucje. „Nawet gdy w łańcuchu legitymizacji istniejącym między obywatelami a instancjami decyzyjnymi w UE pozostały jeszcze pewne słabe miejsca, coraz większa parlamentaryzacja systemu politycznego [UE - przyp. J.R.] wyraźnie przyczynia się do wzmocnienia demokratycznego fundamentu Unii Europejskiej, a powiązania kontrolne w obrębie oraz między poszczególnymi organami wielopoziomowej demokracji europejskiej, które uczestniczą w procesie ustawodawczym, są silniejsze niż kiedykolwiek wcześniej." (Emmanouilidis, 2005, s. 229) ${ }^{26}$. Ponadto główne instytucje kierownicze Unii Europejskiej (zarówno ponadnarodowe jak międzyrządowe) wnoszą swój specyficzny wkład do demokracji ponadnarodowej. Parlament Europejski jest strażnikiem kapitału legitymizacyjnego, którego rola w unijnym systemie instytucjonalnym rośnie z każdym traktatem rewizyjnym między innym dzięki stopniowemu wciąganiu go do procedur legislacyjnych.

Dotąd najmniej demokratyczna, ale za to najbardziej technokratyczna Komisja Europejska nabyła pierwsze rozwiązania demokratyczne dzięki temu, że jej przewod-

Europejskiej z 1992 r. przyznał obywatelom UE tylko rezydującym w innym państwie członkowskim, czynne oraz bierne prawo wyborcze (czyli możliwość kandydowania) w wyborach do Parlamentu Europejskiego oraz w wyborach lokalnych przeprowadzanych w państwach członkowskich, w których przebywa obywatel UE.

26 J. A. Emmanouilidis, Konstytucja europejska z perspektywy niemieckiej, „Nowa Europa” 2005, nr 1 (I), s. 229. 
niczący nominowany jest z grupy politycznej, która wygrała demokratyczne wybory do PE. Ponadto nie możemy zapominać, że choć komisarze nie są demokratycznie wybierani, to jednak w wielu systemach politycznych ministrów także nie wybiera się w demokratycznych wyborach, lecz są oni mianowani.

Z kolei orzecznictwo Trybunału Sprawiedliwości UE jest źródłem procesów demokratyzacji oraz budulcem ponadnarodowych rozwiązań demokratycznych. Z kolei Rada UE, która narzuca najistotniejsze ograniczenia na bieżące przepisy prawne obraduje w gronie przedstawicieli państw, funkcjonariuszy i ministrów działających na podstawie instrukcji krajowych władz wykonawczych, tak jak w swoim kraju" (Moravcsik, 2005, s. 284) i wywodzących się z demokratycznych rządów narodowych.

W końcu Rada Europejska, która umacnia swoją pozycję jako dominująca polityczna instytucja Unii, składa się z demokratycznie wybieralnych liderów krajowych sprawujących bezpośrednio władzę oraz ustalających agendę dla całej UE.

Instytucje Unii Europejskiej są istotnym czynnikiem napędzającym demokratyzację w UE i tym samym przyczyniają się do rozwoju demokracji ponadnarodowej.

\section{Demokratyzacja przez prawo}

Demokracja ponadnarodowa wspierana jest przez ponadnarodowy porządek prawny (supranational legal order) z elementami ponadnarodowego konstytucjonalizmu (supranational constitutionalism $)^{27}$. Próby konstytucjonalizacji UE były wyrazem nie tylko wzmocnienia UE, ale także jej demokratyzacji, chociaż proces konstytucjonalizacji traktatów, a także Wspólnot oraz potem UE był i jest procesem wertykalnym, czyli odbywającym się „od góry”.

System traktatowy UE (prawo pierwotne) stanowi źródło demokratycznych rozwiązań w UE. Zatem międzyrządowo negocjowane i przyjmowane traktaty są istotnym elementem w procesie kreacji demokracji ponadnarodowej. Także system prawa wtórnego Unii Europejskiej, kreowanego przez instytucje UE, posiada istotny wpływ na demokratyczne rozwiązania w UE.

Integracja przez prawo jest więc integracją odgórną. Prawo wspólnotowe w UE jest autonomicznym porządkiem prawnym i wywodzi swoją legitymizację z traktatów założycielskich (w szczególności prawo pierwotne).

Pasquale Policastro uważa, ze naturalnym środowiskiem o charakterze prawnym dla wielopoziomowej demokracji (Multi-Level Democracy), w tym także dla demokracji na poziomie ponadnarodowym, jest wielopoziomowy konstytucjonalizm (Multi-Level Constitutionalism) (Policastro, 2004, s. 70). Oczywiście jeżeli uznamy, że wielopoziomowy konstytucjonalizm można zidentyfikować poprzez konstytucje na poziomie regionalnym (np. w landach niemieckich), konstytucje na poziomie narodowym w państwach członkowskich oraz konstytucję europejska, za którą prawnicy uznają traktaty założycielskie oraz ich rewizje w UE, to wówczas tak skonstruowane

27 Szerzej na temat ponadnarodowego konstytucjonalizmu zob.: J. Nergelius, P. Policastro, K. Urata, Challenges of Multi-Level Constitutionalims, Kraków 2004. 
środowisko prawne, które można nazwać wielopoziomowym konstytucjonalizmem, jest naturalną bazą i źródłem ponadnarodowej demokracji.

\section{Demokratyzacja przez aksjologię}

Demokratyzacja UE może być także emanacją wspólnotowych wartości, którym hołduje UE. Państwa utworzyły Wspólnoty Europejskie oraz Unię Europejską w zgodzie z wymogami prawnymi, które także zostały przez te państwa ustanowione. Kilka fundamentalnych dla Unii Europejskiej wartości przyczyniło się do kreacji demokracji ponadnarodowej. Wśród nich znajdują się przede wszystkim: subsydiarność, solidarność, ochrona praw człowieka i praw mniejszości oraz pluralizm.

Subsydiarność jest demokratyczna bowiem sprzyja decyzjom podejmowanym blisko obywatela. Z tego względu dużą rolę w promowaniu i ochronie wolności indywidualnych odgrywa decentralizacja szczególnie taka, która występuje w postaci podziału władzy pomiędzy różnorodne centra (służyć temu może m.in. subsydiarność). Dzięki tym zabiegom władza znajduje się bliżej obywateli. Dobrym wyznacznikiem wspierania prawa człowieka przez UE jest poparcie, jakie udzieliła ona Międzynarodowemu Trybunałowi Karnemu (International Criminal Court - ICC).

Ponadnarodowa solidarność jest jednym z najważniejszych elementów wpływających na ponadnarodową demokrację (Policastro, 2004, s. 70-71). bowiem buduje jedność i ułatwia podejmowanie decyzji. Ten wpływ na budowę demokracji ponadnarodowej dotyczy zarówno solidarności wertykalnej (między różnymi aktorami na różnych poziomach), jak i horyzontalnej (pomiędzy aktorami usytuowanymi na jednym poziomie).

Ochrona praw człowieka i praw mniejszości jest wartością niemal „wywieszoną na sztandary" w UE. Ochroną tej wartości zajmują się nie tylko odpowiednie instytucje (Trybunał Sprawiedliwość UE, Europejski Rzecznik Praw Obywatelskich, Europejska Agencja Praw Podstawowych itd.), ale i odpowiednie regulacje prawne (np. Karta Praw Podstawowych).

Z kolei wartość pluralizmu, jako jedna z istotniejszych w każdej demokracji ujawnia się w UE pod postacią znanej formuły ,,jedność w różnorodności”. Etno-narodowy lokalizm, z jego bogactwem przyczynia się do pluralizmu w UE, a zatem także do ponadnarodowej demokracji. Unifikacja w UE zakłada homogeniczną przestrzeń, w której różnice mogą być konfigurowane i zabezpieczone jako projekcja pluralizmu zaaranżowana z góry (Ricca, 2015, s. 10). Możemy wskazać na dwie projekcje pluralizmu w UE: 1) infra-state pluralism (dotyczy różnorodnych terytorialnych, zdecentralizowanych, także sfederalizowanych aktorów oraz podmiotów operujących w ,swoistej separacji" od narodów i państw członkowskich (w europejskich regionach, miastach, małych wspólnotach itd.), którzy rozwijają i eksponują swoje zwyczaje, a nawet porządki prawne; 2) exo-state pluralism (dotyczy wymiaru europejskiego nawet globalnego doświadczeń prawnych, kulturowych, politycznych czy ekonomicznych) (Ricca, 2015, s. 10).

Pluralistyczna jest także ponadnarodowa legislacja, co dla przykładu jest widoczne w pluralistycznym zastosowaniu Karty Praw Podstawowych. 
Należy pamiętać, że dla procesów demokratyzacji w UE wagę ma także wzajemne uzupełnianie się, przenikanie wartości oraz ich miksowanie.

\section{Zakończenie}

Demokracja została „przeniesiona” poza swoje naturalne środowisko, jakim jest państwo. To „przeniesienie” demokracji jest elementem szerszego procesu wielokierunkowego przepływu władzy w ramach Unii Europejskiej.

Często eksponowany w literaturze przedmiotu deficyt demokracji w Unii Europejskiej, jest wciąż, sukcesywnie zmniejszany, w tym dzięki rozwojowi demokracji ponadnarodowej. Należy jednak pamiętać, że na poziomie ponadnarodowym trudniej jest osiągnąć demokrację niż na poziomie narodowym. Zresztą, jeżeli UE nie posiada własnego demos, to tym samym nie może ona cieszyć się pełną demokracją w rozumieniu klasycznym, która przecież wywodzi się od demos.

Z przeprowadzonych badań wyłania się kilka wniosków:

1) termin „demokracja ponadnarodowa” jest wielokomponentowy (posiada komponenty wyłączne, komponenty wspólne, substytuty);

2) demokracja ponadnarodowa w Unii Europejskiej generuje nowe formy procesów i rozwiązań demokratycznych (np. by pass, deficyt kontroli, reorganizacja funkcji państw narodowych), które nie były dotąd identyfikowane w demokracji klasycznej;

3) demokracja ponadnarodowa jest wspierana przez ponadnarodowy porządek prawny UE (supranational legal order) z elementami ponadnarodowego konstytucjonalizmu (supranational constitutionalism),

4) demokracja ponadnarodowa jest rodzajem crisp levels democracy o cechach kosmopolitycznych i potrafi reorganizować funkcje państw członkowskich (europeizacja top-down),

5) demokracja ponadnarodowa Unii Europejskiej pokazuje również, że nie tylko naród może być źródłem demokracji i podstawą jej legitymizacji, ale także - w przypadku braku narodu - procesy demokratyzacyjne, które budują i napędzają rozwiązania demokratyczne.

6) źródła demokracji ponadnarodowej ujawniają się w kilku równoległych procesach demokratyzacyjnych w UE (w państwach, wśród obywateli UE, w instytucjach UE, w ponadnarodowym prawie, w aksjologii).

Demokracja ponadnarodowa w Unii Europejskiej jest bardziej przedstawicielska niż partycypacyjna i działa w środowisku bardziej regulacyjnym niż dystrybucyjnym. Jednak jej istnienie dowodzi, że państwo narodowe nie jest jedynym podmiotem, w którym demokracja może zostać efektywnie zbudowana.

\section{Bibliografia}

Arnold R. (2004), The Different Levels of Constitutional Law in Europe and Their Interdependence, w: J. Nergelius, P. Policastro, K. Urata, Challenges of Multi-Level Constitutionalism, Kraków. 
Avbelj M., Komarek J. (2012), Constitutional Pluralism in the European Union and Beyond, Bloomsbury Publishing.

Börzel T., What can Federalism teach us about the European Union? The German Experience, www.riia.org/pdf/research/europe.Borzel/pdf.

Brinks D. M., Leiras M., Mainwaring S. (eds) (2014), Reflecting on uneven democracies: The Legacy of Guilermo O'Donnel, John Hopkins University Press, Baltimore-Maryland.

Czaputowicz J. (2013), Suwerenność, Warszawa.

Das Europäische Parlament und die Tätigkeit der Europäischen Gemeinschaft. Kurzdarstellungen, Europäische Parlament Generaldirektion Wissenschaft, 1988, De III/V.

Dastoli V. (2001), An EU Constitution and federalism after Nice: a New Chance or Requiem for a Myth?, „The International Spectator”, vol. XXXVI, nr 1, January-March.

Delanty G. (1999), Odkrywanie Europy. Idea, tożsamość, rzeczywistość, Warszawa-Kraków.

Dobrobyt, solidarność i bezpieczeństwo. Komisja Wspólnot Europejskich, Strategiczne cele na lata 2005-2009; Europa 2010: Partnerstwo dla odnowy europejskiej (2005), „Międzynarodowy Przegląd Polityczny", nr 11.

Eberlein B., Grande E. (2005), Beyond delegation: transnational regulatory regimes and the EU regulatory state, „Journal of European Public Policy”, vol. 12, nr 1.

Greven M. T., Pauly L. W. (eds.) (2000), Democracy beyond the State. The European Dilemma and the Emerging Global Order, Rowman and Littlefield, Lanham.

Habermas J. H. (1992), Citizenship and National Identity: Some Reflections on the Future of Europe, „Praxis International”, vol. 12, nr 1.

Habermas J. (2005), Czy Europie potrzebna jest Konstytucja?, „Nowa Europa”, nr 1.

Held D. (1995), Democracy and the Global Order. From the Modern State to Cosmopolitan Governance, Cambridge.

Hilary J. (2015), Transatlantyckie partnerstwo $w$ dziedzinie handlu i inwestycji, Warszawa.

Hurrelmann A. (2014), Democracy beyond the State: Insights from the European Union, „Political Science Quarterly", vol. 129, $\mathrm{nr} 1$.

Kassim H., Menon A. (2002), The Principal-Agent Approach and The Study Of The European Union: A Provisional Assessment, The European Research Institute, The University of Birmingham, „Working Paper Series”, 14 July, Birmingham, wersja online: www. eri.bham.ac.uk.

Kieniewicz J. (2004), Andaluzja, Hiszpania i pogranicza cywilizacji: Wspótczesna perspektywa historycznej konfrontacji, w: Cywilizacja europejska. Wykłady i eseje, red. M. Koźmiński, Warszawa.

Kruk M. (2004), Uwagi o projekcie Traktatu ustanawiajacego Konstytucję dla Europy, „Przegląd Sejmowy", nr 2 (61).

Kumm M., To be a European Citizzen: Constitutional Patriotism and the Treaty Establishing a Constitution for Europe, w: E. Oddvar Eriksen, J. E. Fossum, M. Kumm, A. J. Menendez, The European Constitution: The Rubicon Crossed?, Arena Report, Oslo, No 3/05.

Lake D. A. (2013), Theory is dead, long live theory: The end of the Great Debates and the rise of eclecticism in International Relations, „European Journal of International Relations”, vol. 19(3).

Majone G. (1996), Europe's Democratic Deficit. The Question of Standards, „European Law Journal", nr 4, March.

March J. G., Olsen J. P. (2005), Instytucje. Organizacyjne podstawy polityki, Warszawa.

Marshal T. H. (1964), Citizenship and Social Class, w: Class, Citizenship and Social Devvelopment: Essasys by T. H. Marshall, London. 
Mazurkiewicz P. (2001), Europeizacja Europy: Tożsamość kulturowa Europy w kontekście procesów integracji, Warszawa.

Menasse R. (2013), Demokracja nie musi być narodowa. Unia Europejska: pokój na kontynencie a oburzenie obywateli, Warszawa.

Miller J. G. (1978), Living Systems, New York.

Moravcsik A. (2005), Deficyt demokracji - wyolbrzymiony problem, „Nowa Europa”, nr 1(I).

Moravcsik A. (2002), In Defence of the Democratic Deficit. Reassessing Legitimacy in the European Union, „Journal of Common Market Studies”, vol. 40, November.

Nergelius J., Policastro P., Urata K. (2004), Challenges of Multi-Level Constitutionalims, Kraków. Nugent N. (2006), The Government and Politics of the EU, Durham.

O’Donnell G. (1998), Horizontal Accountability in New Polyarchies, ,Journal of Democracy”, vol. 9, $\mathrm{nr} 3$, July.

Pasquino G. (2002), The Democratic Legitimation of European Institution, „The International Spectator", $\mathrm{nr} 4$.

Policastro P. (2004), Constitutionalism, Multi-Level Democracy and Fundamental Values, w: J. Nergelius, P. Policastro, K. Urata, Challenges of Multi-Level Constitutionalism, Kraków.

Price D. H. (2004), Schuman or Monnet? The Real Architect of Europe. Robert Schuman's Speeches and Texts on the Origin, Purpose and Future of Europe, Brussels.

Ricca M. (2015), United Europe and Euclidean Pluralism. On the Anthropological Paradox of Contemporary EU Legal Experience, „UNIO. EU Law Journal”, vol. 1, nr 1, July.

Riggs F. W. (2001), Glocalization, Diasporas and Area Studies, www2.hawaii.edu.

Ruszkowski J. (2010), Ponadnarodowość w systemie politycznym Unii Europejskiej, Warszawa.

Ruszkowski J. (2013), Struktura wielopoziomowego zarzadzania w Unii Europejskiej, w: Multi-level Governance w Unii Europejskiej, red. J. Ruszkowski, L. Wojnicz, Szczecin-Warszawa.

Ruszkowski J. (2012), Teorie specjalistyczne w studiach europejskich, w: J. Ruszkowski, L. Wojnicz, Teorie w studiach europejskich. W kierunku nowej agendy badawczej, Szczecin-Warszawa.

Ruszkowski J. (2007), Wstęp do studiów europejskich. Zagadnienia teoretyczne i metodologiczne, Warszawa.

Sartori G. (2006), Teoria demokracji, Warszawa.

Shapiro I. (2006), Stan teorii demokracji, Warszawa.

Schmidt W. (2006), Democracy in Europe. The EU and National Polities, Oxford.

Schmitter Ph., Lynn K. T. (1991), What Democracy is - And Is Not, ,Journal of Democracy”, vol. 2, Summer.

Sosnowska H. (2000), Wprowadzenie do teorii publicznego wyboru, Rzeszów.

Sroka A. (red.) (2011), Odpowiedzialność w Unii Europejskiej. Rzeczywistość czy iluzja?, Warszawa.

Tocqueville de A. (1999), Listy, wybór, wstęp i opracowanie I. Grudzińksa-Gros, Kraków.

Weiler J. H. H. (1995), The State ,über alles”. Demos, Telos and the German Maastricht Decision, „EUI Working Papers”, No. 19.

Wessels W., Diedrichs U. (1996), The Evolution of the European Parliament. A new Kind of Parlimanet for a New Kind of Political System?, Cologne, March, artykuł w posiadaniu autora.

Wojtaszczyk K. A., Szymańska J. (2012), Deficyt demokracji w Unii Europejskiej, Warszawa.

Wallace W., Smith J. (1995), Democracy or Technocracy? European Integration and the Problem of Popular Consent, „West European Politics”, vol. 18, nr 3.

Weiler J. H. H. (2005), Czy Europa potrzebuje konstytucji? Demos, telos i orzeczenie Niemiec w sprawie traktatu z Maastricht, „Nowa Europa”, nr 1(I). 
Welsh J. M. (1993), A Peoples'Europe? European Citizeznship and European Identity, „EUI Working Papers", ECS No. 93/2, Badia Fiesolana, San Domenico.

Zürn M. (2000), Democratic Governance beyond the Nation-State. The European Union and Other International Institutions, „European Journal of International Relations”, vol. 6, June.

\section{Streszczenie}

W artykule zostały postawione dwa następujące pytania badawcze: jak wygląda demokracja bez narodu (tutaj na przykładzie demokracji na poziomie ponadnarodowym w UE)?, oraz jakie są źródła takiej demokracji, skoro źródłem nie jest naród, a obszarem występowania nie jest państwo?

Głównym paradygmatem teoretycznym, na jakim zostało oparte opracowanie jest teoria ponadnarodowość z elementami teorii demokracji oraz multi-level Governance (MLG). Demokracja ponadnarodowa w Unii Europejskiej, jest ulokowana na jednym, ponadnarodowym poziomie w MLG, co oznacza, że nie jest ona przypisana do państwa $\mathrm{i}$ - co istotne - w praktyce dowodzi, że wcale nie musi ona mieć charakteru narodowego. W tekście pojawia się wstępna próba analizy teoretycznej odnoszącej się do demokracji ponadnarodowej w UE. W praktyce zainteresowania Autora poszły w kierunku identyfikacji komponentów składowych pojęcia „,demokracja ponadnarodowa" oraz źródeł tego zjawiska w Unii Europejskiej.

Słowa kluczowe: demokracja ponadnarodowa, Unia Europejska, ponadnarodowość

\section{Supra-national democracy in the European Union. A preliminary theoretical analysis}

\section{Summary}

This paper seeks answers to the following two research questions: whether it is possible to have democracy without people (here as an example of democracy at the supranational level in the EU), and what are the sources of such a democracy, if the source is not a nation, and the area is not a state?

This paper provides a new approach to the theory of democracy and postulates to integrate a new type of democracy and traditional concept of democracy. The main theoretical paradigm on which the theory was based is supranationalism with elements of the theory of democracy and Multi-level Governance (MLG). Supranational democracy in the European Union is located on a supranational level of MLG, which means that it is not assigned to the state and - importantly - in practice demonstrates that it does not have to have a national character. The text presents a preliminary attempt at a theoretical analysis related to supranational democracy in the EU. In practice, the author goes towards identifying the constituent components of the concept of "supranational democracy" and the sources of this phenomenon in the European Union.

Key words: supranational democracy, European Union, supranationalism 
